\title{
Predictors of Shisha Consumption among Students in Tertiary Institutions: A Systematic Review
}

\author{
Abdulrehman Halima Allahdad ${ }^{*}$, Cromwell Mwiti Kibiti², Rahma Udu Yusuf2, \\ Valentine Budambula ${ }^{1}$ \\ ${ }^{1}$ Department of Environment and Health Sciences, Technical University of Mombasa P.O. Box \\ 90420 - 80100, Mombasa, Kenya; ${ }^{2}$ Department of Pure and Applied Sciences, Technical \\ University of Mombasa, P.O. Box 90420 - 80100, Mombasa, Kenya \\ Corresponding author's email: hallykadrow07@yahoo.com
}

\begin{abstract}
$\mathbf{T}$ obacco use is a risk factor for several diseases, disabilities and premature deaths. Shisha is specially flavoured tobacco and majority of the users perceive hookah smoking to be safer than cigarette. Shisha use has become rampant and trendy among students in tertiary institutions. This review aims to evaluate predictors of shisha consumption among students in tertiary institutions. We reviewed references of authentic databases and journals including Web of Science, PubMed, Iranian Databases, National Agency for the Campaign against Alcohol and Drug Abuse, CDC and WHO. The review focused on data documented from 2010 up to 2020.Predictors of shisha use were: shisha availability and accessibility, flavouring ,gender, awareness level, parental factors, marital status, social acceptability, peer pressure, birth order, monthly stipend, course enrolled in, internet and legal framework on hookah smoking. Most students using shisha reported to be poly drug users with marijuana, tobacco products, alcohol and khat. Most students consume shisha either singly or concurrently or simultaneously alongside other drugs. However, it is not possible to tell if shisha use preceded use of other drugs or was an aftermath. There is need to strengthen laws and policies regulating waterpipe industry. Since nearly all the reviewed literature was based on self-reported history which is prone to both social desirability bias and memory recall bias there is need to have confirmed incidence of shisha use in this sub-population.
\end{abstract}

Key Words: Shisha, Hookah, Tertiary institutions, Shisha adulteration, Poly-druguse

\section{Introduction}

Tobacco consumption is one of the biggest global public health threats that is responsible for more than 8 million deaths (Alwan, 2011). About 7 million deaths are due to direct tobacco use while around 1.2 million areas a result of passive smoking (WHO, 2020).Tobacco smoke contains over 7,000 different chemicals out of which 70 are carcinogenic while several others are toxic and tumor promoters (Mendel et al., 2018).A more trendy way of smoking tobacco is through shisha use (Aslam et al., 2014). Shisha is specially flavoured tobacco that is consumed via a water pipe also known as hookah, narghile, goza or hubble bubble (Qasim et al., 2019).Shisha is marketed in fruit, floral and herbal flavours. Some of the common fruit flavours include: apple, orange, grape, watermelon, cherry among others. Coffee, mint, chocolate, vanilla and coconut are among the popular floral flavours (CDC, 2014; 2016). These flavours make the smoke more aromatic than ordinary cigarette smoke thus become more appealing to the consumer (Qasim et al., 2019).Shisha smoking among students in tertiary institutions has been on the rise worldwide (Rahman et al., 2014). In Kenya, The Public Health Act prohibits the importation, manufacture, distribution, sell and advertisement or promotion of shisha (Government of Kenya, 2017).

Globally the prevalence of water-pipe smoking is estimated to be 100 million with alarming increasing popularity among the youth. This global trend is on the rise as per several epidemiological studies and surveys (Maziak, 
2015). During 2000-2010, the prevalence of tobacco smoking in men reduced in $125(72 \%)$ countries and in women reduced in 156 (88\%) countries, respectively. If these trends continue, only $37(21 \%)$ of countries are on the right track to achieve cessation for men and $88(49 \%)$ for women. This is an estimate of 1.1 billion current smokers (95\% credible interval of 700 million to 1.6 billion) in 2025 (Xia et al., 2018). Rapid increase is predicted in Africa for men and in the Eastern Mediterranean for both men and women. Several low-income and middle-income countries are at risk of worsening tobacco epidemics if these trends remain unchanged (Bilano et al., 2015; WHO, 2016). Generally, in Africa the prevalence has increased to $7.8 \%$ for girls and $36.5 \%$ for boys and is expected to double up by 2030 (WHO, 2020).

Hookah smoking has become increasingly popular among young adults and college students across the world. This is due to increased exposure and popularity of shisha cafes surrounding learning institutions in addition to availability of alternative forms of tobacco such as shisha and shisha pens that has reduced cigarette smoking significantly (Griffiths et al., 2011). A study conducted in the United States of America (USA) in two universities showed that the prevalence of water pipe smokers was $27.8 \%$ (Rahman et al., 2014).Another survey conducted at San Diego University reported the prevalence of water pipe smoking as $24.5 \%$ (Aslam et al., 2014). Still in USA, 16.3\% of the prevalence was associated with misperception, with almost $30 \%$ of those who do not smoke considering smoking water pipe in future. More men than women are reported to be current consumers of hookah. This misperception explains the tremendous increase in hookah smoking (Rahman et al., 2014). Overall, the prevalence of shisha use in European countries and USA was reported at $16 \%$ and $8.4 \%$, respectively (Muzzamil et al., 2019).

In Kenya, the current use of tobacco among the population aged 15-65 years stands at 9.1\% (NACADA, 2014). Cigarette smoking is the most common form of tobacco consumption in Kenya with $8.6 \%$ of the population being current users. Other commonly used forms include sniffed and chewed tobacco (0.7\%) and shisha (0.2\%). However, the trend of shisha use is on the rise. In terms of geographical distribution, North Eastern Kenya has the highest prevalence of current tobacco users at $16.1 \%$ followed by Nairobi and then Central at $14.4 \%$ and $10.2 \%$, respectively (NACADA, 2012). According to NACADA (2012), about $4.5 \%(900,000)$ of the Kenyan population between 15-65 years were dependent on tobacco by the year 2012 .

Majority of hookah smokers especially the young generation believe that shisha smoking is a social entertainment practice, less harmful or less addictive than cigarette smoking (Grekin \& Ayna, 2012). This popularity is due to the misconception that the nicotine content in shisha is lower than that of cigarettes and that water used in this form of tobacco intake works as a filter thus removing all the hazardous chemicals such as carbon monoxide, nicotine as well as tar. These common misapprehensions lead public to believe that shisha smoking is not hazardous (Rehman et al., 2014). However, shisha smoking carries a higher risk as compared to cigarette smoking. For example, one hookah session of tobacco smoking delivers 50 to100 times the smoke volume of a single cigarette and it contains about 40 times the tar in cigarettes. Furthermore, it contains 30 times the carcinogenic polycyclic aromatic hydrocarbons, 2 times the nicotine and 10 times the carbon monoxide level of the smoke present in a single cigarette (Barnett et al., 2011; Cob et al., 2011; CDC, 2013; Fromme \& Schober, 2017). Even though shisha use is detrimental, many individuals continue to use it as it is perceived to have a low potential for harm and addictiveness (Abughosh et al., 2011; Griffiths et al., 2011; Lipkus et al., 2011).

Tobacco use is a risk factor for preventable causes of developing diseases, disabilities and premature deaths in the world (Kumar et al., 2014; WHO, 2020). Tobacco contains approximately 4,000 chemicals, of which at least 250 are known to be harmful and 70 carcinogenic (WHO, 2017). Furthermore, existing literature indicate that there is a relationship between smoking with different malignancies such as cancer of the lungs, mouth, throat, stomach, eosophagus, pharynx, larynx, pancreas, breast, 
kidneys, ureter, bladder, blood and genitals (Kassem et al., 2014; Calvanes et al., 2015; Budambula \& Budambula, 2017). Additionally, the effect of tobacco smoke on bronchoconstriction escalates tracheal tension increasing the risk of chronic bronchitis, emphysema and precipitation of asthma as well as pneumonia (Mishra et al., 2015; Budambula \& Budambula, 2017; Claire et al., 2020).Moreover, tobacco smoking is a known risk factor for cardiovascular disorders like heart failure, arterial fibrillation, venous thromboembolism, ischemic cardiovascular disease among others (Khan et al.,2015; Amiri et al.,2019; Kondo et al.,2019).

Other effects of tobacco particularly in women during pregnancy include: low birth weight, premature birth, spontaneous abortions, both foetal and infant death (El-Zaatari et al., 2015; Waziry et al., 2017). Pipe sharing is also a risk factor in transmission of communicable diseases such as tuberculosis, hepatitis B and C through sharing of the mouth piece among consumers with mouth ulcers or bleeding gums (Qassim et al., 2019). Besides that, the unhygienic hookah apparatus, sharing of the mouth piece and water used may harbor and precipitate growth of bacteria like Aspergillus, Helicobacter pylori and Mycobacteria which are pathogens for pneumonia, peptic ulcers and tuberculosis, respectively (Qassim et al., 2019). Additionally, tobacco consumption is also associated with mental health disorders as its use is associated with anxiety, stress, depression and other psychological disorders especially during chronic and withdrawal syndromes (Prochaska et al., 2017; King et al., 2018).

\section{Shisha Preparation and Contents}

Shisha is prepared by burning of flavoured tobacco over coal or wood fuel. It contains high levels of polycyclic aromatic hydrocarbons (PAHs) like benzo-a-pyrene which is a carcinogen (Avagyan, 2016). The heated tobacco produces smoke that passes through water and then drawn through a rubber hose to a mouthpiece where it is finally smoked (Sepetdjian et al., 2010; Fig. 1). A typical session of shisha smoking lasts 20-80 minutes, with shisha smokers taking up to 200 puffs. In contrast, cigarette smoking typically takes about 5-8 minutes with 8-12 puffs (Meo et al., 2017).

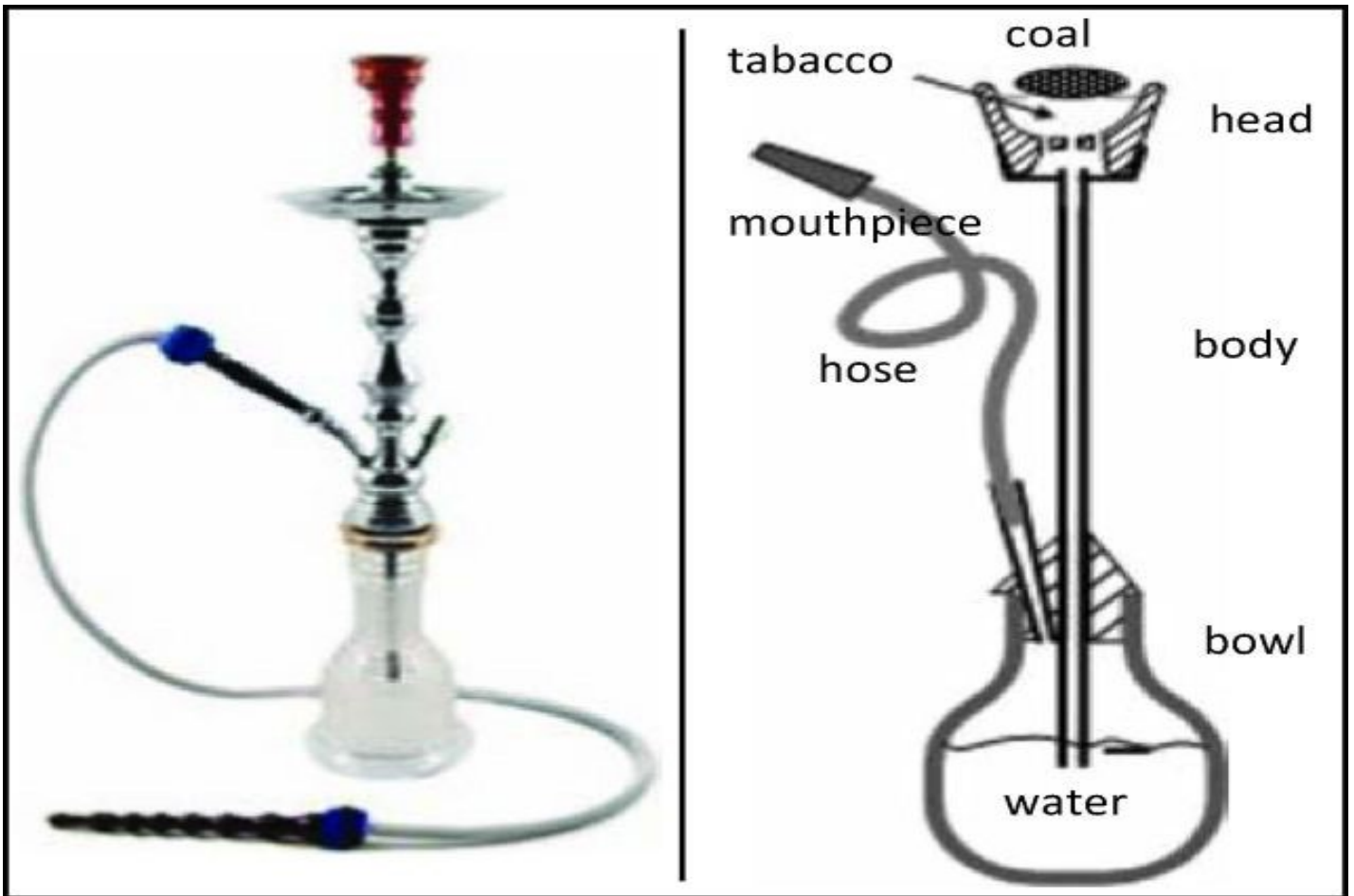

Figure 1.Waterpipe picture (left) and schematic showing main parts (right) (Adopted from Maziak, 2013)

Published: May 2021 


\section{Methodology}

This review was conducted using comprehensive and systematic literature reports on the use of shisha among university and college students globally. Empirical searches were conducted using Google Scholar (http://www. scholar. google.com), and Science Direct (http://www. science direct.com), Web of Science, PubMed, Medline, Iranian Databases, National Agency for the Campaign against Alcohol and Drug Abuse, Centre for Disease Control (CDC) and World Health Organization (WHO). The review focused on the predictors of shisha use and the health effects on users particularly among university as well as college students. Key publications and other articles were accessed through tracking citations or directly through journal websites. About 150 scientific studies conducted from 2010 up to 2020 were accessed. The keyword combinations for the search were shisha, hookah, narghile, gooza, shashaman, water pipe consumption, risk factors, hubble bubble, shisha adulteration, poly drug use and effects on health.

\section{Findings and Discussion}

Based on the literature reviewed, our findings and discussion focuses on the following predictors of shisha among students in tertiary institutions:

\section{Availabilityand accessibility}

Generally, availability of tobacco products in the local markets as well as ease of access influences their use (Yen et al., 2012). In Kenya tobacco farming, distribution and consumption is legal but regulated (Government of Kenya, 2019). However this restriction excludes use of shisha which is currently banned (Government of Kenya, 2017). However, in other countries such as Rwanda and USA, shisha availability in cafes, bars and restaurants are among the driving forces for students to consume shisha (Omotehinwa et al., 2018; Kalan et al., 2021).The ease of availability and access to shisha in homes, restaurants as well as coffee shops is an influential factor that leads the young individuals' familiarity with hookah smoking (Dehdari et al., 2012). Shisha use is socially acceptable and associated with entertainment, having fun with friends and family, peer pressure, and imitation as the most significant reasons for smoking hookah (Pashaeypoor et al., 2019).

\section{Flavours}

Sinceshisha is marketed in fruit, floral and herbal flavours, this flavouring gives it a pleasant and tantalizing aroma. These flavours make the smoke more aromatic than ordinary cigarettes smoke thus become more appealing to the consumer (CDC, 2016; Qasim et al., 2019). The pleasant aroma of shisha has been reported as one of the reasons leading to the introduction of none smokers to this practice (Syed et al., 2015; Aanyu et al., 2019).

\section{Gender}

Generally men have a higher likelihood of smoking shisha than females hence more male students are more likely to smoke shisha than their counterparts (Redhwan, 2011; Lasebikan et al., 2019). In most cultures, while men are allowed to use drugs, females are restricted or frowned at hence being female is a protective factor (Timuti et al., 2012; Becker et al., 2017). For example, during male circumcision the newly circumcised individuals are allowed to consume drugs as a rite of passage. Moreover, tobacco consumption including other drugs is perceived as a rite of passage for men in most communities as it signals maturity and a sense of belonging.

\section{Awareness level}

Majority of students who smoke shisha lack correct information about the shisha content. They believe that shisha is healthy because of the flavours and it is safer because of the water that filters the smoke making it less toxic as compared to cigarette smoking (Erbaydar et al., 2010; Heinz et al., 2013). However, the smokers are not aware that hookah smoking involves consumption of large volume of smoke which includes nicotine, carbon monoxide, tar and several carcinogenic compounds (Fromme \& Schober, 2017; Traboulsi et al., 2020). Moreover, a high percentage of students who consume shisha believe that hookah is less or not addictive and hence they can easily quit shisha smoking as compared to cigarette smoking (Abughosh et al., 2011; Griffiths et al., 2011; Lipkus et al., 2011). The water pipe is also perceived to provide a positive somatic experience that engages almost all the senses including taste, 
smell, sight, hearing and touch (Akl et al., 2015). Most students who consume shisha report using shisha for the following reasons: to relieve stress, depression, negative emotions and fatigue; to achieve calmness; to improve on social relationships; to improve concentration and selfefficiency; to fit into peer groups; as a pastime activity; and as a way of having new experience (Joveyni et al., 2012; Daniel \&Roman 2013; Khalil et al., 2013).

\section{Parental influence}

Students whose parents use tobacco products including shisha are likely to be exposed at a relatively early age and this heightens the risk of using the same or other types of drugs (Ramji et al., 2015; Budambula \& Budambula, 2017). The risk of students wanting to experiment or becoming addicted has been attributed to genetic and family environmental factors. Most students tend to copy parental behaviours at the same time parents who smoke are more likely to grant easy access to tobacco products and are less likely to oppose their children's smoking (D'Souza et al., 2012; Dwivedi et al., 2013; Edward et al., 2020). Perception that parents can approve or disapprove their children's substance use can influence sibling's initiation to drugs (Loke \& Mak, 2013). Overall, parental use of nicotine contributes to intergenerational transmission of smoking (Mays et al., 2014).

\section{Parental marital status}

Students raised by single parent households have a higher likelihood of using shisha compared to those with dual parents (Zhang et al., 2012; Mojallal et al., 2017). Single parents may have financial crisis, less time to provide and monitor their children. Therefore, less parental supervision causes peer dependency for information related to appropriate behaviours, hence they are at risk to substance use and abuse (Budambula \& Budambula, 2017). Similarly, in a study carried out in Iran, among Iranian university students reported low level of family monitoring and positive parents attitude towards substance abuse (Taremian et al., 2018). Studies carried out in USA, Sweden and Africa has similar findings (Odukoya et al., 2013; Ramji et al., 2015).

\section{Poor parenting skills}

Students whose parents use dictatorship style of parenting tend to rebel and sometimes use drugs as a sign of rebellion (Loke \& Mak, 2013; Stanton et al., 2014). On the other hand, children with liberal parents and those whose parents use laissez faire style of parenting tend to take advantage of their parents permissive nature (Shakya et al., 2012; Wood et al., 2019).

\section{Parental absenteeism}

Absence of either or both parents due to death, marital separation, long distance relationship or nature of occupation has been associated with shisha smoking. The link between parental absenteeism and early smoking can be attributed to reduced parental supervision and selfmedication against stress, deprivation as well as stress (Sajjadi et al., 2015; Lacey et al., 2018). Students from household with low income may experience less or lax supervision by the single parent and socially are likely to rely heavily on peers. This increases their vulnerability to tobacco use and other recreational drugs. Conceivably, present parent may be more condone on the newly acquired habits or even too busy working to be fully aware (Park et al., 2012; Smith \&Wilson, 2016).

\section{Marital status}

The unmarried students tend to have no responsibilities apart from their academic performance, hence spend their income on entertainment and drug use. Additionally, new students on campus especially the unmarried are vulnerable to peer influence (Omotehinwa et al., 2018). In this case, the likelihood of shisha use could be due to separation related stress or boredom hence hooked up to shisha as a way of coping mechanism (Park et al., 2017).

\section{Social acceptance}

Social acceptance also has a significant role in influencing hookah smoking compared to cigarette smoking among students. Generally, about $45 \%$ of youth have a favorable perception towards shisha smoking regarding it as fashionable, trendy and socially acceptable health behaviour globally (Jawad et al., 2016). 
Age

Age of the students when tobacco was first initiated predicts shisha use later in life. Parents, guardians including other family members and friends using students to purchase tobacco influence their use (Ololade et al., 2015) at an early age. These adults are primarily family members, older friends and neighbors within the community. Availability of retail tobacco to underage persons is one of the highest exposures of students to drug use at an innocent age (Bonnie et al., 2015). Although the Tobacco Act in Kenya prohibits this, some families are either ignorant or deliberately breech the law (Government of Kenya, 2007).

\section{Peer pressure}

Peer pressure and perceived popularity is the biggest driving force of addiction and the most common cause of all types of drugs initiation irrespective of age brackets (Ramji et al., 2015). Most students use shisha to gain acceptance by peers, relieve stress and cope up with difficult circumstances (Yen et al., 2012). Peer pressure is a major stimulus for actions of teenagers during maturation as well as drug initiation. As a result, teenagers are more prone to choose the friends or be welcomed by the peers who smoke shisha (Othman et al., 2019; Pashaeypoor et al., 2019). The feeling of belonging to fit in a particular group may precipitate shisha and other substance usages (Ramji et al., 2015). Additionally, university students have freedom compared to high school where there is parental as well as institutional control (Atwoli et al., 2011). The presence of other individuals like close relatives or a friend who smoke hookah is significantly associated with the youth's smoking hookah (Karimy et al., 2013).

\section{Birth order}

Out of the literature reviewed, about $16.6 \%$ of students were reported to be first borns. These children were reported to be more likely to use shisha as most parents pay attention at the same time place exorbitant pressure in such children (Lander et al., 2013). At the same time being the only child or a last born also increases the risk of shisha use as a result of having poor coping skills due to overprotection. In most family set ups the lastborn child often has the position of the baby in the family. They are likely to be more pampered through deprivation of independence (Valkov, 2018). Other students are likely to suffer from drug use as a result of poor coping skills resulting to emotional roller coaster (Eckstein \& Kaufman, 2012).

\section{Monthly stipend}

Students receiving high amounts of pocket money are likely to indulge in shisha use. Unlike other drugs where poverty is a risk factor, moderate pocket money is a risk factor for shisha use in university or college students. About $56 \%$ of the literature reviewed reported students who receive pocket money amounting between USD50-100 were more likely to use shisha. Additionally, students having more than USD 50 a week increased the odds of shisha usage globally (Cheloti \& Gathumbi, 2016; Huang et al., 2017).

\section{Internet access}

Establishments dedicated to hookah smoking have proliferated internet in order to promote shisha consumption (Asfar et al., 2019). Most of the websites $(16.6 \%)$ belonging to these establishment slack age requirement to view or age verification mechanism (Primack et al., 2012). In addition, most did not display tobacco-related warning messages and rarely mentioned the word tobacco. A number of websites promoted messages that implied hookah smoking was safer than cigarette or displayed images of people having fun or sexually suggestive images. Other websites $(11.1 \%)$ promoted messages that emphasized relaxation and pleasure or the social aspect of hookah tobacco smoking like people gathered to socialize in a peaceful environment (Primack et al., 2012; Jawad et al., 2016; Salloum et al., 2019). Majority of students are heavy internet users and solemnly rely on the information they get from internet (Limayem \& Cheung, 2011; Apuke et al., 2018). These media may serve as 'super-peer' by promoting hookah use as students are likely to observe, mimic and model their behaviours to what they view (Griffiths et al., 2011; Elmore et al., 2017). The internet and other media platforms also play a role in enhancing or propagating deceptive information related to hookah tobacco smoking targeting the youthful population (Singh et al., 2018; Wang et al., 2019). 


\section{Role of religion}

Religious beliefs are reversely associated with the consumption of tobacco products and religious reasons are found as the major factors in quitting or not smoking hookah. In fact, commitment to religious beliefs plays a protective role against the consumption of tobacco products (Khan et al., 2012). Globally, majority of the journals reported higher prevalence of shisha use among the Christian faith despite the originality of the product from the Middle East.

\section{Course enrolled}

Majority of students use shisha, although a higher prevalence is reported in business, computer science and engineering related academic disciplines (Omotehinwa et al., 2018; Kabbash \& Saied 2019). Drug use in engineering and medicine academic disciplines could be due to such courses being too demanding as compared to other science courses. Hence students may suffer overall academic stress as a result of pressure to perform, fear of failure, increased number of supplementary examinations, fear of discontinuation due to poor academic performance among other factors (De Castella et al., 2013).These are well known predictors for drug use.

\section{Low self-esteem and self-control}

About $40 \%$ of the literature reviewed reported students with a lower self-esteem are more likely to be initiated into tobacco use (Khosravi et al., 2016; Anbarlouei et al., 2018). Low self-esteem predicts low resistance skills and increases vulnerability to depression. Depression is a known risk factor for tobacco use at the same time tobacco use heightens the odds for depressive episodes (Primack et al., 2013; Fluharty et al., 2017). This could be attributed to the fact that younger people may use tobacco as a form of selfmedication for emotional distress (CarcellerMaicas et al., 2014). Lack of ability to resist friends' offer, inability to withstand temptation for smoking shisha during celebrations or gatherings are some of the reasons as to why students get initiated into smoking waterpipe (Karimy et al., 2013; Othman et al., 2019).

\section{Legal framework}

There exist several regulatory loopholes that make hookah smoking more accessible and attractive to youth. For example, although most countries have comprehensive laws and policies on cigarette smoking some allow hookah tobacco smoking (HTS) via exemptions or by not mentioning HTS at all (Morris et al., 2012; Primack et al., 2012). Additionally, there is no deterrence law for supplying hookah to minors in coffee shops making shisha easily accessible (Hammal et al., 2015). Even though some countries have clear laws on HTS, a significant proportion of students lack awareness on legislations against shisha use (Zavery et al., 2017). Overall there exists a gap between availability of strict inhibitive laws against hookah consumption and their execution (Dadipoor et al., 2019).

\section{Poly-drug use}

Majority of shisha users rarely use it singly but with combination with other $\operatorname{drug}(\mathrm{s})$, a phenomenon known as poly-drug use. This is defined as the use of more than one drug type by an individual, often at the same time or sequentially and usually with the intention of enhancing, potentiating or counteracting the effects of another drug (Budambula \& Budambula 2017; WHO, 2020). Several studies demonstrate a substantial overlap between shisha and marijuana smoking among university students (Primack et al., 2012; Sutfin et al., 2014; Mehra et al., 2019). Other studies report alcohol use before, during and after shisha smoking. Further, alcohol appears to enhance the hookah smoking experience and may play a role in hookah smoking initiation (Fielder et al., 2015). A significant number of shisha using students also reported consumption of cigarettes, cigars, little cigars or cigarillos (LCCs) and e-cigarettes (Abudayyeh et al., 2018; Muzammil et al., 2019). Most importantly, ever using shisha increases the risk of khat chewing. Tobacco, marijuana and alcohol are considered as gateway drugs to illicit substances like cocaine and heroin in adulthood (Miller \& Hurd, 2017).

\section{Conclusion and Recommendation}

This review concludes that predictors of shisha use are; shisha availability and accessibility, flavouring, gender, awareness level, parental 
factors, marital status, social acceptability, peer pressure, birth order, monthly stipend, course enrolled in, religion, internet advertisements, poly-drug use and legal framework on hookah smoking. This paper therefore, recommends for upscaling awareness campaigns on hookah tobacco smoking targeting both students and parents. It is also important to train students on drug resistance skills and healthy self-esteem as well as formulate, review and effectively implement laws and policies on hookah tobacco smoking.

\section{Acknowledgement}

This review paper was a success due to the available physical and online library resources from Technical University of Mombasa.

\section{References}

Aanyu, C., Kadobera, D., Apolot, R.R., Kisakye, A.N., Nsubuga, P., Bazeyo, W. \&Ddamulira, J.B. (2019). Prevalence, knowledge and practices of shisha smoking among youth in Kampala City, Uganda. The Pan African Medical Journal, 32:61

Abudayyeh, H.S., Glasser, A.M., Johnson, A.L., Cohn, A.M., Wagener, T.L., Mays, D. \&Villanti, A.C. (2018). Social and substance use correlates of adult hookah use, 2016. Addictive Behaviors, 79: 39-44

Abughosh, S., Wu, I.H., Peters, R.J., Essien, E.J. \& Crutchley, R. (2011). Predictors of persistent waterpipe smoking among university students in the United States. Epidemiology, 1(102): 2161-1165

Akl, E.A, Ward, K.D., Bteddini, D., Khaliel, R., Alexander, A.C., Lotfi, T., Alaouie, H. \&Afifi, R.A. (2015). The allure of the waterpipe: A narrative reviewof factors affecting the epidemic rise in waterpipe smoking among young person's globally. Tobacco Control, 24 (1): i13-i21

Alwan, A. (2011). Global status report on noncommunicable diseases 2010. World Health Organization.

Amiri, P., Mohammadzadeh-Naziri, K., Abbasi, B., Cheraghi, L., Jalali-Farahani, S., Momenan, A.A., Amouzegar, A., Hadaegh, F. \&Azizi, F. (2019). Smoking habits and incidence of cardiovascular diseases in men and women: findings of a 12 year follow up among an urban Eastern-Mediterranean population. BMC Public Health, 19(1), 1042

Anbarlouei M, Sarbakhsh P, Dadashzadeh H, Ghiasi A, Ataieasl M, Dorosti A. \& Mohammadpoor, A. (2018). Cigarette and hookah smoking and their relationship with self-esteem and communication skills among high school students. Health Promotion Perspective, 8(3):230-236

Apuke, O.D. \&Iyendo, T.O. (2018). University students' usage of the internet resources for research and learning: forms of access and perceptions of utility. Heliyon, 4(12): e01052

Asfar, T., Ben Taleb, Z., Osibogun, O., RuanoHerreria, E.C., Sierra, D., Ward, K.D., Salloum, R.G. \&Maziak, W. (2019). How Do Waterpipe Smoking Establishments Attract Smokers? Implications for Policy. Substance Use EMisuse, 54(4): 560-571

Aslam, H.M., Saleem, S., German, S. \& Qureshi, W.A. (2014). Harmful effects of shisha: Literature review. International Archives of Medicine, 7 (16): 2-9

Atwoli, L., Mungla, P.A., Ndung'u, M.N., Kinoti, K.C. \&Ogot, E.M. (2011). Prevalence of substance use among college students in Eldoret, western Kenya. BMC Psychiatry, 11(1): 1-9

Avagyan, R., Nyström, R., Lindgren, R., Boman, C. \& Westerholm, R. (2016). Particulate hydroxy-PAH emissions from a residential wood log stove using different fuels and burning conditions. Atmospheric Environment, 140:1-9

Barnett, T.E., Curbow, B.A., Soule Jr, E.K., Tomar, S.L. \&Thombs, D.L. (2011). Carbon monoxide levels among patrons of hookah cafes. American Journal of Preventive Medicine, 40(3): 324-328

Becker, J.B., McClellan, M.L. \& Reed, B.G. (2017). Sex differences, gender and addiction. Journal of Neuroscience Research, 95(1-2): 136-147

Bilano, V., Gilmour, S., Moffiet, T., d'Espaignet, E.T., Stevens, G.A., Commar, A. \& Shibuya, K. (2015). Global trends and projections for tobacco use, 1990-2025: An analysis of smoking indicators from the WHO Comprehensive Information Systems for Tobacco Control. The Lancet, 385(9972):966976 
Bonnie, R.J., Stratton, K. \& Kwan, L.Y. (eds). (2015). Public health implications of raising the minimum age of legal access to tobacco products. Washington, DC: National Academies Press

Budambula, V., \&Budambula, N. L. M. (2017). Chasing the dragon: drug use and abuse. ISBN-13:978-9966-103-02-4, ISBN10:9966103023

Calvanese, A.V., Bingham, M.V., Martinasek, M.P. \& Friesen, B.K. (2015). Understanding attitudes, beliefs, and information seeking regarding hookah smoking in parents of college students: an exploratory qualitative pilot study.Respiratory Care, 60 (7): 959-966

Carceller-Maicas, N., Ariste, S., Martínez-Hernáez, A., Martorell-Poveda, M.A, CorreaUrquiza, M. \& DiGiacomo, S.M. (2014). El consumo de tabacocomoautomedicación de depresión/ansiedad entre los jóvenes: resultados de un estudio con métodomixto [Smoking as a form of self-medication for depression or anxiety in young adults: results of a mixed-methods study]. Adicciones, 26(1):34-45

Claire, S., Gouda, H., Schotte, K., Fayokun, R., Fu, D., Varghese, C. \& Prasad, V. M. (2020). Lung health, tobacco, and related products: gaps, challenges, new threats, and suggested research. American Journal of Physiology-Lung Cellular and Molecular Physiology, 318(5): L1004-L1007

CDC. (2013). Preventing Chronic Diseases: Investing Wisely in Health. The Critical role of school health programs. http://www.cdc.gov/nccdphp/publications /factsheets/Prevention/pdf/schoolhealth.p df. (Accessed on 24 th $A$ pril 2013)

CDC. (2014). Smoking and tobacco use: hookah. http://www.cdc.gov/tobacco/data statistics/factsheets/tobaccoindustry/hoo kah/index.htm (Accessed on $8^{\text {th }}$ October 2013)

CDC. (2016). Smoking and Tobacco Use. http://www.cdc.gov/tobacco/data statistics/factsheets/tobaccoindustry/hoo $\mathrm{kah} /$ index.htm (Accessed on 10 $10^{\text {th }}$ November 2015)

Cheloti, S.K. \& Gathumbi, A.M. (2016). Curbing drug and substance abuse in secondary schools in Kenya; the disconnect in school community intervention strategies. South Estern university journal41.(89);31-335

Cobb, C.O., Shihadeh, A., Weaver, M.F. \&Eissenberg, T. (2011).Waterpipe tobacco smoking and cigarette smoking: a direct comparison of toxicant exposure and subjective effects.Nicotine Tobacco Research, 13(2):78-87

D'Souza, G., Rekha, D.P., Sreedaran, P., Srinivasan, K. \& Mony, P.K. (2012). Clinicoepidemiological profile of tobacco users attending a tobacco cessation clinic in a teaching hospital in Bangalore city. Lung India, 29: 137-142

Dadipoor, S., Kok, G., Aghamolaei, T. Ghaffari, M., Heyrani, A., \& Ghanbarnezhad, A. (2019). Explaining the determinants of hookah consumption among women in southern Iran: A qualitative study. BMC Public Health, 19: 1655

Daniels, K.E. \& Roman, N.V. (2013). A descriptive study of the perceptions and behaviors of waterpipe use by university students in the Western Cape, South Africa. Tobacco Induced Diseases, 11(1):4

De Castella, K., Byrne, D. \& Covington, M. (2013). Unmotivated or motivated to fail? A crosscultural study of achievement motivation, fear of failure, and student disengagement. Journal of Educational Psychology, 105(3): 861

Dehdari, T., Jafari, A. \&Joveyni, H. (2012). Students' perspectives in Tehran University of Medical Sciences about factors affecting smoking hookah. Razi Journal of Medical Sciences, 19(95):17-24

Dwivedi, S., Aggarwal, A., Singh, N., Aggarwal, S. \& Sharma, V. (2013). Role of family milieu in tobacco addiction: A study in a tertiarycare institution in India. Journal Health Population Nutrition, 31: 130-132

Eckstein, D. \& Kaufman, J.A. (2012). The role of birth order in personality: An enduring intellectual legacy of Alfred Adler. Journal of Individual Psychology, 68(1): 60-74

Edwards, K.C., Sharma, E., Halenar, M.J., Taylor, K.A., Kasza, K.A., Day, H. \& Stanton, C.A. (2020). Longitudinal pathways of exclusive and polytobacco cigar use among youth, young adults and adults in the USA: findings from the PATH Study Waves 1-3 
(2013-2016). Tobacco control, 29(Suppl 3): s163-s169

Elmore, K.C., Scull, T.M. \& Kupersmidt, J.B. (2017). Media as a "Super Peer": How Adolescents Interpret Media Messages Predicts Their Perception of Alcohol and Tobacco Use Norms. Journal of Youth and Adolescence, 46(2): 376-387

El-Zaatari, Z.M., Chami, H.A. \&Zaatari, G.S. (2015). Health effects associated with waterpipe smoking. Tobacco Control, 24(Suppl 1): i31i43

Erbaydar, N.P., Bilir, N. \& Yildiz, A.N. (2010). Knowledge, behaviours and health hazard perception among Turkish narghile (waterpipe)-smokers related to narghile smoking. Pakistan Journal of Medical Sciences, 26(1): 195-200

Fluharty, M., Taylor, A.E., Grabski, M. \&Munafò, M.R. (2017). The Association of Cigarette Smoking With Depression and Anxiety: A Systematic Review. Nicotine \& Tobacco Research, 19(1): 3-13

Fromme, H. \& Schober, W. (2017). Die Wasserpfeife (Shisha)-Innenraumluftqualität, HumanBiomonitoring und Gesundheitseffekte. Der Pneumologe, 14(4): 250-264

Government of Kenya (2017). The Public Health Act 2017 (Cap. jnn242). The Public Health http://www.kenyalaw.org/kl/fileadmin/ pdfdownloads/Acts/PublicHealthActCap 242.pdf

(Accessed on May 2018)

Government of Kenya (2019). The Tobacco Control Act 2019. The Tobacco Control http://www.kenyalaw.org/kl/fileadmin/ pdfdownloads/Acts/TobaccoControlAct. (Accessed on January 2020)

Government of Kenya (2007). The Tobacco Act 2019. The Tobacco Act http://www.kenyalaw.org/kl/fileadmin/ pdfdownloads/Acts/TobaccoAct.

(Accessed on November 2017)

Grekin, E.R. \& Ayna, D. (2012). Waterpipe smoking among college students in the United States: A review of the literature. Journal of American College Health, 60(3): 244-249

Griffiths, M.A., Harmon, T.R. \& Gilly, M.C. (2011). Hubble bubble trouble: the need for education about and regulation of hookah smoking. Journal of Public Policy $\mathcal{E}$ Marketing, 30(1): 119-132

Hammal, F., Wild, T.C., Nykiforuk, C., Abdullahi, K., Mussie, D., Finegan, B.A. (2015). Waterpipe (hookah) smoking among youth and women in Canada is new, not traditional. Nicotine Tobacco Research, 18(5):757-62

Heinz, A.J., Giedgowd, G.E., Crane, N.A., Veilleux, J.C., Conrad, M., Braun, A.R., ... \& Kassel, J.D. (2013). A comprehensive examination of hookah smoking in college students: use patterns and contexts, social norms and attitudes, harm perception, psychological correlates and co-occurring substance use. Addictive Behaviors, 38(11): 2751-2760

Huang, L.L., Sutfin, E.L., Kowitt, S., Patel, T., Ranney, L. \& Goldstein, A. O. (2017). Trends and correlates of hookah use among high school students in North Carolina. North Carolina Medical Journal, 78(3): 149-155

Jawad, M., Choaie, E., Brose, L., Dogar, O., Grant, A., Jenkinson, E. \&Shahab, L. (2016). Waterpipe tobacco use in the United Kingdom: a crosssectional study among university students and stop smoking practitioners. PLoS ONE, 11(1): e0146799

Joveyni, H., Dehdari, T. \& Gohari, M. (2013). Waterpipe smoking in the male college students: an education intervention using theory of planned behavior. Journal of Research and Health, 3(4): 497-503

Kabbash, I.A. \& Saied, S.M. (2019). Perception and Practices of Shisha Smoking among Kafr ElSheikh University Students, Egypt. Egyptian Journal of Community Medicine, 38(2): 58-69

Kalan, M.E., Rahman, A., Gautam, P. \& Taleb, Z.B. (2021). Hookah home delivery: an emerging public health issue. Tobacco Control, 30(1):114-115

Karimy, M., Niknami, S., Heidarnia, A.R., Hajizadeh, E. \& Shamsi, M. (2013). Refusal self-efficacy, self-esteem, smoking refusal skills and water pipe (Hookah) smoking among Iranian male adolescents. Asian Pacific Journal of Cancer Prevention, 14(12):7283-7288

Kassa, A., Wakgari, N. \& Taddesse, F. (2016). Determinants of alcohol use and khat chewing among Hawassa University 
students, Ethiopia: Across sectional study. African Health Sciences, 16(3): 822-830

Kassem, N.O., Kassem, N.O., Jackson, S.R., Liles, S., Daffa, R.M., Zarth, A.T. \&Hovell, M.F. (2014). Benzene uptake in Hookah smokers and non-smokers attending Hookah social events: regulatory implications. Cancer Epidemiology and Prevention Biomarkers, 23(12): 2793-2809

Khalil, J., Afifi, R., Fouad, F.M., Hammal, F., Jarallah, Y., Mohamed, M. \&Nakkash, R. (2013). Women and waterpipe tobacco smoking in the eastern Mediterranean region: allure or offensiveness. Women \& Health, 53(1): 100116

Khan, R.J., Stewart, C.P., Davis, S.K., Harvey, D.J. \& Leistikow, B.N. (2015). The risk and burden of smoking related heart disease mortality among young people in the United States. Tobacco Induced Diseases, 13(1): 16

KhanMogaddam, R., Shojaezadah, D., Sadeghi, R., Pahlevanzadah, B. \& Shakourimoghaddam, R.(2012). Survey of prevalence and causes of the trend of hookah smoking in Tehran University Students of Medical Sciences 2010-2011. Tolooe Behdasht, 11(4):103-113

Khosravi, A., Mohammadpoorasl, A., HolakouieNaieni, K., Mahmoodi, M., Pouyan, A.A., \&Mansournia, M.A. (2016). Causal effect of self-esteem on cigarette smoking stages in adolescents: coarsened exact matching in a longitudinal study. Osong Public Health and Research Perspectives, 7(6): 341-345

King, J.L., Reboussin, B.A., Spangler, J., Ross, J.C. \& Sutfin, E.L. (2018). Tobacco product use and mental health status among young adults. Addictive Behaviors, 77: 67-72

Kondo, T., Nakano, Y., Adachi, S. \& Murohara, T. (2019). Effects of tobacco smoking on cardiovascular disease. Circulation Journal, 83(10): 1980-1985

Kumar, V., Talwar, R., Roy, N., Raut, D. \& Singh, S. (2014). Psychosocial determinants of tobacco use among school going adolescents in Delhi, India. Journal of Addiction, 170941: 1-6

Lacey, R.E., Zilanawala, A., Webb, E., Abell, J., \& Bell, S. (2018). Parental absence in early childhood and onset of smoking and alcohol consumption before adolescence. Archives of Disease inChildhood, 103:691-694
Lander,L., Howsare, J. \& Byrne, M, (2013). The Impact of Substance Use Disorders on Families and Children: From Theory to Practice. Social WorkingPublic Health, 28(0): 194-205

Lasebikan, V.O., Ola, B.A. \&Lasebikan, T.O. (2019). Shisha smoking in selected nightclubs in Nigeria. The Pan African Medical Journal, 33 (136): 2-11

Limayem, M. \& Cheung, C.M.K. (2011). Predicting the continued use of Internet-based learning technologies: the role of habit, behaviour andinformation technology. Behaviour $\mathcal{E}$ Information Technology, 30 (1): 91-99

Lipkus, I.M., Eissenberg, T., Schwartz-Bloom, R.D., Prokhorov, A.V. \& Levy, J. (2011). Affecting perceptions of harm and addiction among college waterpipe tobacco smokers. Nicotine $\mathcal{E}$ Tobacco Research, 13(7): 599-610

Loke, A.Y. \& Mak, Y. (2013). Family Process and Peer Influences on Substance Use by Adolescents. International Journal of Environmental Research and Public Health, 10 (9): 3868-3885

Mays, D., Gilman, S.E., Rende, R., Luta, G., Tercyak, K.P., Niaura, R.S. (2014). Parental smoking exposure and adolescent smoking trajectories. Pediatrics, 133(6):983-91

Maziak, W. (2013). The waterpipe: an emerging global risk for cancer. Cancer Epidemiology, 37(1):1-4

Maziak, W., Taleb, Z.B., Bahelah, R., Islam, F., Jaber, R., Auf, R. \& Salloum, R.G. (2015). The global epidemiology of waterpipe smoking. Tobacco Control, 24(Suppl 1): i3-i12

Mehra, V.M., Keethakumar, A., Bohr, Y.M., Abdullah, P. \& Tamim, H. (2019). The association between alcohol, marijuana, illegal drug use and current use of Ecigarette among youth and young adults in Canada: results from Canadian Tobacco, Alcohol and Drugs Survey 2017. BMC Public Health, 19(1): 1208

Mendel, J.R., Baig, S.A., Hall, M.G., Jeong, M., Byron, M.J., Morgan, J.C., Noar, S.M., Ribis, K.M. \& Brewer, N.T. (2018). Brand switching and toxic chemicals in cigarette smoke: A National Study. PLoS ONE, 13(1): $1-10$

Meo, S.A, Bashir,S, Almubarak, Z, Alsubaie, Y., Almutawa, H. (2017). Shisha smoking: 
impact on cognitive functions impairments in healthy adults. European Review for Medical and Pharmacological Sciences, 2: 52175222

Miller, M.L. \& Hurd, Y.L. (2017). Testing the Gateway Hypothesis. Neuropsychopharmacology, 42(5): 985-986

Mishra, A., Chaturvedi, P., Datta, S., Sinukumar, S., Joshi, P. \&Garg, A. (2015). Harmful effects of nicotine. Indian Journal of Medical and Paediatric Oncology: Official Journal of Indian Society of Medical EPaediatric Oncology, 36(1): 24-31

Mojallal, M., Hosseinkhanzadeh, A.A., Taher, M., Yahyazadeh, A. (2017). Parent-child relationship and smoking among college students: role of parents in females' and males' smoking behavior. Practical Clinical Psychology, 5(2):81-90

Morris, D.S., Fiala, S.C. \& Pawlak, R. (2012). Opportunities for policy interventions to reduce youth hookah smoking in the United States. Preventing Chronic Diseases, 9:120082

Muzammil, D.S., Al Rethaiaa, A.S., Al Mutairi, A.S., Al Rashidi, T.H., Al Rasheedi, H.A. \& Al Rasheedi, S.A. (2019). Prevalence and perception of shisha smoking among university students: A cross-sectional study. Journal of International Society of Preventive \& Community Dentistry, 9(3): 275

NACADA. (2012).2012 Report: Rapid situation assessment of the status of drug and substance in Kenya. NACADA, Nairobi. 54

NACADA. (2014). Status of shisha and kuber use in Kenya. Policy Brief No. NAC/15/2014: 1-3

Odukoya, O.O., Odeyemi, K.A., Oyeyemi, A.S. \& Upadhyay, R.P. (2013). Determinants of smoking initiation and susceptibility to future smoking among school-going adolescents in Lagos State, Nigeria. Asian Pacific Journal Cancer Prevention, 14(3): 174753

Ololade, O.O., Obi, C.J., Odeyemi, K.A. \&Nwangwu, G.I. (2015). Young people's awareness and support for tobacco control legislation: A study among in-school youth in Lagos, Nigeria. Nigerian Quarterly Journal of Hospital Medicine, 25(3): 193-201

Omotehinwa, O.J., Japheths, O., Damascene, I.J. \& Habtu, M. (2018). Shisha use among students in a private university in Kigali city, Rwanda: prevalence and associated factors. BMC Public Health, 18(1): 713

Othman, M., Aghamohammadi, N. \&NikFarid, N. (2019). Determinants of shisha use among secondary school students in Sudan. BMC Public Health 19: 1390

Park, S.H, Dustin, D.T., Shahawy, O.E., Shearston, J.A., Lee, L., Tamura, K., Sherman, E. \& Weitzman, M. (2017). Analysis of statespecific prevalence, regional differences, and correlates of hookah use in U.S. adults, 2012-2013, Nicotine E Tobacco Research, 19 (11): 1365-1374

Pashaeypoor, S., Negarandeh, R., Nikpeyma, N. \&Abadi, Z.A.M. (2019). Determinants of intentions toward smoking hookah in Iranian adolescents based on the theory of planned behaviour. Iranian Journal of Public Health, 48(7): 1317

Primack, B.A., Hopkins, M., Hallett, C., Carroll, M.V., Zeller, M., Dachille, K., Kim, K.H., Fine, M.J. \& Donohue, J.M. (2012). US health policy related to hookah tobacco smoking. American Journal of Public Health, 102(9): e47e51

Primack, B. A., Land, S. R., Fan, J., Kim, K. H., \& Rosen, D. (2013). Associations of mental health problems with waterpipe tobacco and cigarette smoking among college students. Substance use $\mathcal{E}$ misuse, 48(3), 211-219.

Prochaska, J.J., Das, S. \& Young-Wolff, K.C. (2017). Smoking, mental illness, and public health. Annual Review of Public Health, 38: 165-185

Qasim, H., Alarabi, A.B., Alzoubi, K.H., Karim, Z.A., Alshbool, F.Z. \& Khasawneh, F.T. (2019). The effects of hookah/waterpipe smoking on general health and the cardiovascular system. Environmental Health and Preventive Medicine, 24 (58): 2-17

Rahman, S., Chang, L., Hadgu, S., Salinas-Miranda, A.A. \&Corvin, J. (2014). Peer reviewed: Prevalence, Knowledge, and practices of hookah smoking among university students, Florida, 2012. Preventing Chronic Disease, 11: E214

Ramji, R., Arnetz, J., Nilsson, M., Jamil, H., Norström, F., Maziak, W. \&Arnetz, B. (2015). Determinants of waterpipe use amongst adolescents in Northern Sweden: a 
survey of use pattern, risk perception, and environmental factors. BMC Research Notes, 8(1): 441

Redhwan Ahmed, A. L. \&Saghir, F.S. (2011). Water pipe (shisha) smoking and associated factors among Malaysian university students. Asian Pacific Journal of Cancer Prevention, 12: 3041-3047

Sajjadi, H., Harouni, G.G. \&Sani, M.S. (2015). Personal, familial and environmental determinants of drug abuse: a causalcomparative study. Global Journal of Health Science, 7(4): 367

Salloum, R. G., Lee, J., Mostafa, A., Abu-Rmeileh, N. M., Hamadeh, R. R., Darawad, Maziak. W. \& Nakkash, R. (2019). Waterpipe tobacco smoking among university students in three Eastern Mediterranean countries: Patterns, place, and price. Substance use $\mathcal{E}$ misuse, 54(14), 2275-2283.

Sepetdjian, E., Saliba, N. \&Shihadeh, A. (2010). Carcinogenic PAH in waterpipe charcoal products. Food and Chemical Toxicology, 48(11): 3242-3245

Shakya, H.B., Christakis, N.A. \& Fowler, J.H. (2012). Parental influence on substance use in adolescent social networks. Archives of Paediatrics EAdolescent Medicine, 166(12): 1132-1139

Singhet, N., Jawad, M., Darzi, A., Nakkash, R., Hawkins, B. \& Akl, E.A. (2018). Features of the waterpipe tobacco industry: A qualitative study of the third International Hookah Fair. F1000Res, 7: 247

Smith, V.C. \& Wilson, C.R. (2016). Families affected by parental substance use. Paediatrics, 138(2):e20161575

Stanton, C.A., Highland, K.B., Tercyak, K.P., Luta, G. \&Niaura, R.S. (2014). Authoritative parenting and cigarette smoking among multi-ethnic preadolescents: the mediating role of anti-tobacco parenting strategies. Journal of Paediatric Psychology, 39(1): 109119

Sutfin, E.L., Song, E.Y., Reboussin, B.A. \& Wolfson, M. (2014). What are Young Adults Smoking in their Hookahs? A Latent Class Analysis of Substances Smoked. Addictive Behaviors, 39(7): 1191-1196

Syed, N., Rani, K. \&Memon, M.Q. (2015). ShishaSmoking; popularity and familiarity among
University Students of Jamshoro and Hyderabad, Sindh, Pakistan. Professional Medical Journal-Quarterly, 22(2):200-203

Taremian, F., Yaghubi, H., Pairavi, H., Hosseini, S.R., Zafar, M. \&Moloodi, R. (2018). Risk and protective factors for substance use among Iranian university students: a national study. Substance Abuse Treatment, Prevention and Policy, 13(1): 1-9

Tumuti, S., Wang'eri, T., Waweru, E. W., \& Ronoh, A. K. (2014). Prevalence, drugs used, sources, and awareness of curative and preventive measures among Kenyatta University students, Nairobi County, Kenya. Journal of Emerging Trends in Educational Research and Policy Studies, 5(3), 352.

Traboulsi, H., Cherian, M., Rjeili, M.A, Preteroti, M., Bourbeau, J., Smith, B.M., Eidelman, D.H. \& Baglole, C.J. (2020). Inhalation Toxicology of Vaping Products and Implications for Pulmonary Health. International Journal of Molecular Sciences, 21 (3495): 1-31

Valkov, P. (2018).Birth order and its relatedness to substance use disorder: an empirical resea in Bulgaria. International Journal of Emotional Education, 10 (2): 154 - 158

Wang, Y., McKee, M., Torbica, A. \& Stuckler, D. (2019). Systematic Literature Review on the Spread of Health-related Misinformation on Social Media. Social Science \& Medicine, 240: 112552

Waziry, R., Jawad, M., Ballout, R.A., Al Akel, M. \&Akl, E.A. (2017). The effects of waterpipe tobacco smoking on health outcomes: an updated systematic review and metaanalysis. International Journal of Epidemiology, 46(1): 32-43

Wood, L., Greenhalgh, E.M.,Vittiglia, A.\& HanleyJones, S. (2019). The home environment. In Scollo, M.M. \& Winstanley, M.H. Tobacco in Australia: Facts and issues. Melbourne: Cancer Council Victoria. http://www.tobaccoinaustralia.org.au/ch apter-5-uptake/5-7-the-home-

environment. (Accessed on January 2020)

WHO. (2017). Advisory note: Waterpipe tobacco smoking: health effects, research needs and recommended actions by regulators. http://www.who.int/tobacco/global 
interaction//tobreg/(Accessed on $8^{\text {th }}$ October 2013)

WHO. (2016). Guidelines on the protection from exposure to tobacco Smoke. http://www.who.int/fctc/cop/art $\% 208 \%$ 20guideline-english.pdf

WHO. (2020). Framework convention on tobacco control advocating for even stronger policies against the tobacco epidemic. http:/ / www.who.int/news-room/factsheets/deatil/tobacco. (Accessed on March 2020)

Xia, P., Zhang, Z. \& Sun, X. (2018). Smoking dynamics with health education effect. AIMS Mathematics, 3(4): 584-599

Yen, K.P. (2012). Contributory factors to the smoking of shisha among teenagers in the Perak City of Ipoh: A preliminary qualitative survey. International Journal of Public Health Research, 2(1): 80-84

Zavery, A., Qureshi, F., Riaz, A., Pervez, F., Iqbal, N., Khan, J.A. (2017). Waterpipe (shisha) use and legislation awareness against shisha smoking amongmedical students: A study from Karachi, Pakistan. Journal of Community Health, 42(3):461-465

Zhang, X., Martinez-Donate, A.P., Kuo, D., Jones, N.R. \& Palmersheim, K.A. (2012). Trends in home smoking bans in the USA, 1995-2007: Prevalence, discrepancies and disparities. Tobacco Control, 21(3):330-336 